\title{
Effect of Ksheera Vaitarana Vasti, Janu Vasti along with Adjuvant Ayurveda Drugs in the management of Sandhigatavata (Osteoarthritis in knee joint)- A case study
}

\author{
H.D.R. Fernando, ${ }^{1}$ E.R.H.S.S. Ediriweera, ${ }^{2 *}$ K.D.C.M. Weerasinghe ${ }^{3}$ \\ ${ }^{1} 5^{\text {th }}$ BAMS Scholar, Institute of Indigenous Medicine, University of Colombo, Rajagiriya, Sri \\ Lanka \\ ${ }^{2}$ Senior Professor, Department of Nidana Chikithsa, Institute of Indigenous Medicine, University \\ of Colombo, Rjagiriya, Sri Lanka \\ ${ }^{3}$ Retired Medical Office, Ayurveda Teaching Hospital, Borella, Sri Lanka
}

\begin{abstract}
:
Sandhigatavata is a disease with Shoola (pain), Shotha (swelling) and Hanti Sandhi Gatah Sandhi (impairment of the functions of joints). This can be correlated with osteoarthritis. Osteoarthritis is a degenerative arthritis. While any joint can be affected in osteoarthritis, knee joint is most commonly affected. Vangasena Samhitha mentions Ksheera Vaitarana Vasti as a treatment for Janu Sankocha (stiffness of joint), Kati Prushta Shoola Shotha (swelling and pain in waist, knee and back). Prasarana Akunchanayoh Pravrutthishca Savedana (pain during contraction and extension of limbs) is described as a symptom of Sandhigatavata and stiffness in joint is a symptom of osteoarthritis. Sri Lankan traditional physician family 'Weerasinghe' treat Sandhigatavata with Belimul Thippilimul Amu Inguru Kashaya with effective results. Gugguladi Thaila is described in Sri Lankan Ayurveda Pharmacopeia in treatment of Vata Roga. Susruta advises to conduct Snehana in treatment of Vata Roga. Janu Vasti is one method of administering Bhahya Snehana to Janu Sandhi (knee joint). A 65 years old female with an 8 years history of Sandhigatavata was given Ayurveda treatments for 21 days. Ksheera Vaitarana Vasti was conducted for seven days and from Day 8 to 21, with oral administration of Belimul Thippilimul Amu Inguru Kashaya along with Janu Vasti using Gugguladi Thaila. After completion of treatment, it was observed that swelling, tenderness and pain during contraction and extension of limbs were completely relived. It is concluded that above treatment regimen is effective in treatment of Sandhigatavata (osteoarthritis).
\end{abstract}

Key words: Belimul Thippilimul Amu Inguru Kashaya, Gugguladi Thaila, Ksheera Vaitarana Vasti, Osteoarthritis, Sandhigatavata.

Received: 07.05.2021 Revised: 15.06.2021 Accepted: 25.06.2021 Published: 28.06.2021

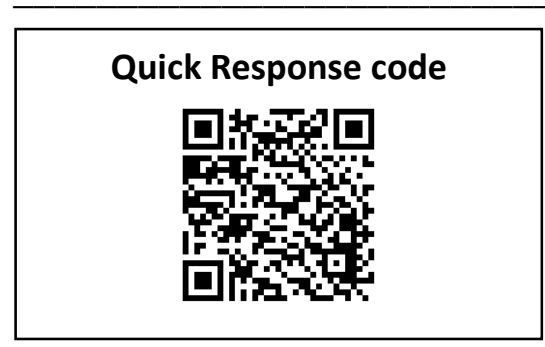
*CORRESPONDING AUTHOR:
Senior Prof. (Mrs.) E.R.H.S.S. Ediriweera
Senior Professor, Department of Nidana Chikithsa,
Institute of Indigenous Medicine, University of Colombo, Rajagiriya, Sri Lanka
E-mail : ayurvedadocsujatha@yahoo.com 


\section{INTERNATIONAL JOURNAL OF AYUSH CASE REPORTS (IJA-CARE)}

Introduction:

Sandhigatavata is a disease described under Vata Roga and its clinical features are Shoola (pain), Shopha (swelling) and Hanti Sandhi Gatah Sandhi (impairment of their functions). ${ }^{[1]}$ Sandhigatavata can be correlated with osteoarthritis. Pain in affected joints and occasional swelling, stiffness in the morning for short period or after resting, limitation of movement in the joint with fine or coarse crepitus and wasting of muscles at the involved joint are the clinical features of Osteoarthritis. ${ }^{[2]}$ Osteoarthritis most commonly affects the hands, lower back, neck, and weight-bearing joints such as knees, hips, and feet.

Ashtanga Hrdaya describes Vasti Karma as the best treatment for Vata Roga. ${ }^{[3]}$ Ksheera Vaitarana Vasti is described in Vangasena Samhita and is advised to administer in treatment of Kati Prushta Shoola Shotha (swelling and pain in waist, knee and back), Anila Ghoram (severe Vata disorders), Chiram Urusthambha (chronic stage / stiffness and loss of control of the leg), Grudhrasi Roga (sciatica), Janu Sankocha (stiffness in knee), Vishama Jwara (intermittent fever) and Klavaiya (erectile dysfunction). ${ }^{[4]} \quad$ Prasarana Akunchanayoh Pravrutthishca Savedana (pain during contraction and extension of limbs) is described as a symptom of Sandhigatavata ${ }^{[5]}$ and stiffness in joints as a symptom of Osteoarthritis. ${ }^{[6]}$ Therefore, Ksheera Vaitarana Vasti is effective in Sandhigatavata.

Traditional physician family Weerasinghe prescribes Belimul Tippilimul Amu Inguru Kashaya in treatment of Sandhigatavata (Osteoarthritis) with effective results. Gugguladi Thaila is a medicated oil described in Sri Lankan Ayurveda Pharmacopeia and advised to prescribe in treatment of Emma or Awililla (muscular pain), Handi Idimum (swelling of joints) and Nahara Kekkuma (neural pain) . ${ }^{[7]}$ Susruta advises to conduct Snehana in treatment of VataRoga. ${ }^{[8]}$ Janu Vasti is one method of administering external oleation to Janu Sandhi (knee joint). No scientific study has been conducted to evaluate the effect of these treatments. Hence it was decided to study the effect of Ksheera Vaitharana Vasti, oral administration of Belimul Tippilimul Amu Inguru Kashaya and Janu Vasti using Gugguladi Thaila in treatment of Sandhigatavata (Osteoarhritis).

\section{Case Report:}

A 56 years old woman suffering from Sandhigatavata (Osteoarthritis) was admitted to National Ayurveda Teaching Hospital, Borella. Her complaints were Shotha (Swelling), Shoola (Pain), Prasarana Akunchanayoh Pravrutthishca Savedana (pain during contraction and extension of limbs), tenderness, Hanti Sandhi Gatah Sandhi (impairment of functions in flexion and extension), stiffness in the morning for short periods of time and crepitus on movement. The patient was thoroughly examined, detailed history was recorded, laboratory investigations and radiological examinations ( $\mathrm{X}$ ray in both knee joints) were carried out. The patient's written consent was obtained in order to publish the data. Severity of the symptoms were recorded using a specially prepared grading scale as given below.

\section{Therapeutic intervention:}

The patient was treated for 21 days. From Day 1 to Day7, patient was treated with Ksheera Vaitarana Vasti. From Day 8 to Day 21, patient was treated orally with $120 \mathrm{ml}$ of Belimul Thippilimul Amu Inguru Kashaya twice a day along with Janu Vasti using Gugguladi Thaila.

\section{Preparation of the trial drugs:}

Method of preparation of Ksheera Vaitharana Vasti $^{[4]}$

$20 \mathrm{~g}$ of jaggery of Saccharum officinarum was scraped and mixed with $10 \mathrm{ml}$ of water so as to 


\section{INTERNATIONAL JOURNAL OF AYUSH CASE REPORTS (IJA-CARE)}

make it thick as honey. $10 \mathrm{~g}$ of rock salt was added to it and churned well. $30 \mathrm{ml}$ of sesame oil was added little by little while stirring. $40 \mathrm{~g}$ of ripen fruits of Tamarindus indica was seeded and weighed. $15 \mathrm{ml}$ of water was added to it and squeezed well. The resultant cream was added to the aforesaid mixture. Then $190 \mathrm{ml}$ of Cow's milk was added to this while churning. The resultant mixture was used as Ksheera Vaitarana Vasti.

\section{Method of preparation of Belimul Tippilimul Amu Inguru Kashaya: \\ It is a Sri Lankan traditional preparation. $20 \mathrm{~g}$ each of roots of Aegle marmelos and Piper longum and fresh rhizome of Zingiber officinale was taken, cut into small pieces and mixed together. $1920 \mathrm{ml}$ of water was added to this mixture and boiled down to $240 \mathrm{ml}$.}

\section{Method of preparation of Gugguladi Thaila ${ }^{[7]}$} First, 480g of Shodhitha Guggulu (purified resin of Commiphora wightii) was measured. Then $3840 \mathrm{ml}$ of vinegar and $3840 \mathrm{ml}$ of lime juice was mixed together and Shoditha Guggulu was dissolved well in this mixture. After that $960 \mathrm{ml}$ of castor oil was heated on a slow fire till the frothy appearance is disappeared. The mixture of vinegar, lime juice, and Guggulu was added to castor oil little by little while heating on mild fire. The mixture was stirred continuously and heated till the oil reaches Madhya Paka. When oil reaches Madyama Paka, it was removed from fire and kept for cooling. When oil becomes cool, it was filtered using a clean cloth and filled into clean glass bottles. (In Madyama Paka stage, the Kalka (residue remaining in oil) became harder and was easy to prepare a Varti (pellet) by rolling. When a small piece of cloth dipped in oil, lighted and burned, it burns without crackling sounds and froth (Phena) appears in the oil.
Procedure of Ksheera Vaitarana Vasti Karma

Purva Karma (preparatory procedure):

Snehana (oleation) and Swedana (sudation) were carried out before administration of Vasti as Purva Karma. Snehana (oleation) was carried out by applying sesame oil on lower abdomen and lumbar sacral region. Swedana was carried out using steam. A piece of cloth was dipped in boiling water and wrung. Steam emitting from the cloth was used for fomentation.

Pradhana Karma (main procedure): After performing Snehana and Swedana, patient was made to lie on a bed in left lateral position with extended left leg and flexed right leg. The left hand was bent at the elbow, so that the palm could be placed under the head. The anal orifice of the patient and rectal catheter was lubricated using sesame oil. Prepared medicines for Ksheera Vaitarana Vasti was put into the enema can which was connected to lubricated rectal catheter. Then the rectal catheter was inserted into the anal orifice. Patient was advised to breathe slowly and deeply. The rectal catheter was removed slowly while a small quantity of enemata remained in Enema can.

Paschat Karma (post therapeutic measures): After administration of Vasti, patient's palms and soles were massaged, and the buttocks were tapped.

Procedure of Janu Vastiusing Gugguladi Thaila:

Powdered black gram (Oorid Dhal) was mixed with water and a paste was prepared. Two rings were made to a height of 10 centimeters each using this paste and placed on knee joints. Then it was sealed well by pressing down the edges of the ring around the knee joint. Then, $120 \mathrm{ml}$ of lukewarm Gugguladi Thaila was poured in to the cavity inside the walled boundary in a constant and continuous stream. It was allowed to remain there for about 45 minutes. Height of oil was 2 inches from the highest point of knee (Fig-1). 


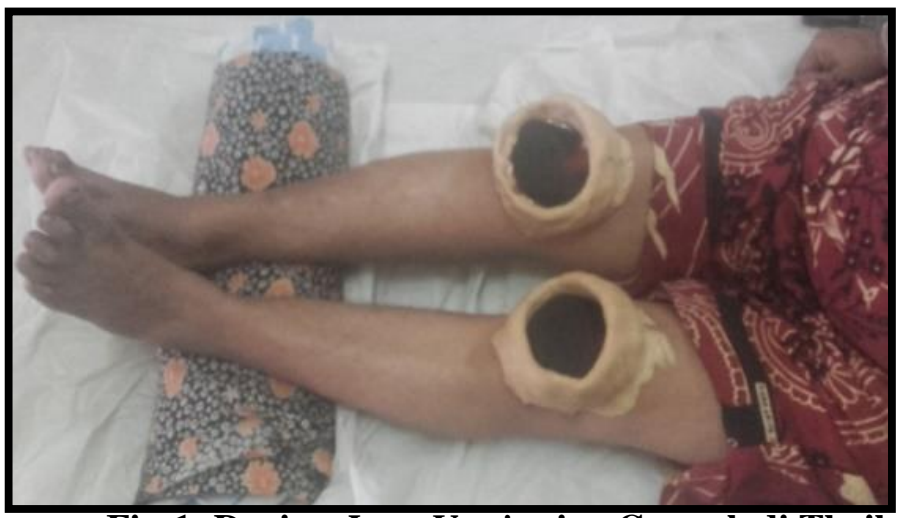

Fig-1: During Janu Vasti using Gugguladi Thaila

Table 1: Assessment of symptoms:

\begin{tabular}{|c|c|c|c|c|c|}
\hline \multirow[t]{2}{*}{ Clinical Features } & \multirow{2}{*}{$\begin{array}{l}\text { BT } \\
\text { Grading }\end{array}$} & \multicolumn{2}{|c|}{$\begin{array}{l}\text { After } \quad \text { Ksheera } \\
\text { Vaitarana }\end{array}$} & \multicolumn{2}{|c|}{$\begin{array}{l}\text { After completion of } \\
\text { entire treatment }\end{array}$} \\
\hline & & Grading & $\begin{array}{l}\text { Percentage } \\
\text { of relief }(\%)\end{array}$ & Grading & $\begin{array}{l}\text { Percentage } \\
\text { of relief }(\%)\end{array}$ \\
\hline Shoola (Pain) & 3 & 3 & $0 \%$ & 1 & $66 \%$ \\
\hline Shotha (Swelling) & 1 & 1 & $0 \%$ & 0 & $100 \%$ \\
\hline $\begin{array}{l}\text { Prasarana Akunchanayoh } \\
\text { Pravrutthishca Savedana (pain } \\
\text { during contraction and extension of } \\
\text { limbs) }\end{array}$ & 2 & 2 & $0 \%$ & 1 & $50 \%$ \\
\hline $\begin{array}{l}\text { Hanti Sandhi Gatah Sandhi } \\
\text { (impairment of functions inflexion) }\end{array}$ & 2 & 2 & $0 \%$ & 1 & $50 \%$ \\
\hline $\begin{array}{l}\text { Hanti Sandhi Gatah Sandhi } \\
\text { (impairment of functions in } \\
\text { extension) }\end{array}$ & 1 & 1 & $0 \%$ & 0 & $100 \%$ \\
\hline Morning stiffness & 2 & 2 & $0 \%$ & 1 & $50 \%$ \\
\hline Crepitus on movement & 3 & 3 & $0 \%$ & 3 & $0 \%$ \\
\hline Joint deformities & 1 & 1 & $0 \%$ & 1 & $0 \%$ \\
\hline Tenderness & 1 & 1 & $0 \%$ & 0 & $100 \%$ \\
\hline
\end{tabular}


INTERNATIONAL JOURNAL OF AYUSH CASE REPORTS (IJA-CARE)

Table 2: Ayurveda pharmacodynamic properties of Ksheera Vaitarana Vasti

\begin{tabular}{|c|c|c|c|c|c|}
\hline Ingredients & Rasa & Guna & Veerya & Vipaka & Actions \\
\hline Rock salt & Lavana & $\begin{array}{l}\text { Laghu, } \\
\text { Snigdha }\end{array}$ & Sheeta & Madhura ${ }^{[9]}$ & $\begin{array}{l}\text { Shotahara, } \\
\text { Tridoshashamaka }^{[9]}\end{array}$ \\
\hline $\begin{array}{l}\text { Tamarindus indica } \\
\text { Linn }\end{array}$ & $\begin{array}{l}\text { Amla } \\
\text { Madhura }\end{array}$ & $\begin{array}{l}\text { Guru, } \\
\text { Ruksha }\end{array}$ & Ushana & $A m l a^{[10]}$ & Vatahara $^{[10]}$ \\
\hline $\begin{array}{l}\text { Saccharum } \\
\text { officinarum Linn }\end{array}$ & Madhura & $\begin{array}{l}\text { Guru } \\
\text { Snigdha }\end{array}$ & Sheeta & Madhura $^{[11]}$ & Vatapittashamaka $^{[11]}$ \\
\hline Cow's milk & Madhura & $\begin{array}{l}\text { Mrudu } \\
\text { Snigdha } \\
\text { Guru, } \\
\text { Manda }\end{array}$ & Sheeta & Madhura $^{[12]}$ & $\begin{array}{l}\text { Vata Pittahara, } \\
\text { Rasayana }^{[12]}\end{array}$ \\
\hline Sesame oil & $\begin{array}{l}\text { Madhura, } \\
\text { Kashaya, } \\
\text { Tiktha }\end{array}$ & $\begin{array}{l}\text { Guru } \\
\text { Snigdha }\end{array}$ & Ushana & Madhura $^{[11]}$ & $\begin{array}{l}\text { Vatashamaka, } \\
\text { Vedanasthapana }^{[11]}\end{array}$ \\
\hline
\end{tabular}

Table 3: Ayurveda pharmacodynamic properties of Belimul Thippilimul Amu Inguru Kashaya ${ }^{[11]}$

\begin{tabular}{|c|c|c|c|c|c|}
\hline Ingredients & Rasa & Guna & Veerya & Vipaka & Actions \\
\hline $\begin{array}{l}\text { Aegle marmelos } \\
\text { Correa }\end{array}$ & $\begin{array}{l}\text { Kashaya } \\
\text { Tikta }\end{array}$ & Ruksha, Laghu & Ushna & $\operatorname{Katu}^{[11]}$ & $\begin{array}{l}\text { Vatashamaka, } \\
\text { Shotahara }^{[11]}\end{array}$ \\
\hline $\begin{array}{l}\text { Piper longum } \\
\text { Linn }\end{array}$ & Katu & $\begin{array}{l}\text { Laghu, Snigdha, } \\
\text { Thikshna }\end{array}$ & Anushnasheeta & Madhura $^{[11]}$ & $\begin{array}{l}\text { Vatakapha } \\
\text { Shamana, Balya }{ }^{[11]}\end{array}$ \\
\hline $\begin{array}{l}\text { Zingiber } \\
\text { officinale Roscoe }\end{array}$ & Katu & $\begin{array}{l}\text { Laghu, Ruksha, } \\
\text { Thikshna }\end{array}$ & Ushana & Madhura $^{[11]}$ & $\begin{array}{l}\text { Kaphavatashamaka } \\
\text { Vedanasthapana, } \\
\text { Shotahara }^{[11]}\end{array}$ \\
\hline
\end{tabular}

Table4: Ayurveda pharmacodynamic properties of Gugguladi Thaila:

\begin{tabular}{|c|c|c|c|c|c|}
\hline Ingredients & Rasa & Guna & Veerya & Vipaka & Actions \\
\hline $\begin{array}{l}\text { Shoditha Guggul } \\
\text { (Commniphora } \\
\text { wightii (Arnott) } \\
\text { Bhandri) }\end{array}$ & $\begin{array}{l}\text { Tikta } \\
\text { Katu }\end{array}$ & $\begin{array}{l}\text { Laghu } \\
\text { Tikshana }\end{array}$ & Ushna & $\operatorname{Katu}^{[11]}$ & $\begin{array}{l}\text { Vatashamana, } \\
\text { Vedanasthapana, } \\
\text { Shotahara }^{[11]}\end{array}$ \\
\hline $\begin{array}{lr}\text { Dehi } & \text { (Citrus } \\
\text { aurantifolia } & \text { Swingle) }\end{array}$ & Amla & Laghu & Ushana & $\begin{array}{l}\text { Madhura } \\
\text { [13] }\end{array}$ & Kaphavatashamaka ${ }^{[13]}$ \\
\hline $\begin{array}{l}\text { Vinakiri (Fermented } \\
\text { sap of Cocus } \\
\text { nucifera } \text { Linn) }\end{array}$ & Not found & Not found & Not found & Not found & Not found \\
\hline $\begin{array}{l}\text { Erandu Thel (Ricinus } \\
\text { communis Linn) }\end{array}$ & $\begin{array}{l}\text { Madhura } \\
\text { Katu } \\
\text { Kashaya }\end{array}$ & $\begin{array}{l}\text { Snigdha } \\
: \\
\text { Sukshma }\end{array}$ & Ushna & $\begin{array}{l}\text { Madhura } \\
\text { [11] }\end{array}$ & $\begin{array}{l}\text { Kaphavatashamaka, } \\
\text { Vedanasthapana, } \\
\text { Angamard prashamana, } \\
\text { Shotahara }{ }^{[1]]}\end{array}$ \\
\hline
\end{tabular}




\section{Results and Discussion:}

After conducting Ksheera VaitaranaVasti none of the symptoms were relived. After completed of entire treatment it was observed that Shotha (Swelling), Prasarana Akunchanayoh Pravrutthishca Savedana (pain during contraction and extension of limbs), and tenderness were completely relived (Table.1)

In Sandhigatavata, Vata and Kapha Dosha are vitiated. Vasti is one of therapeutic measure used in treatment of Vata Roga. ${ }^{[3]}$ The ingredients of Ksheera Vaitarana Vasti contain Madhura Rasa, Ushna Veerya and Madhura Vipaka (Table 2). Due to these properties, it pacifies vitiated Vata Dosha. These ingredients have the properties of Kashaya and Tikta Rasa, Laghu and Ruksha Guna and Ushna Veerya Due to these properties it pacifies vitiated Kapha Dosha. Hence Ksheera Vaitarana Vasti is beneficial in treatment of Vata Roga including Sandhigatavata.

Ayurveda pharmacodynamic properties of ingredients of Belimul Thippilimul Amu Inguru Kashaya are given in. Ingredients of Belimul Thippilimul Amu Inguru Kashaya possess Ushna Veerya (Table-3). Due to this it pacifies vitiated Vata Dosha. These ingredients have the properties of Katu Rasa, Laghu, Ruksha, Ushna and Tikshana Guna and Ushna Veerya. Due to these properties, it pacifies vitiated Kapha Dosha. Hence Belimul Thippilimul Amu Inguru Kashaya is beneficial in treatment of Vata Roga including Sandhigatavata.

Janu Vasti is a method of Bahira Snehana (external oleation). As Snehana is one of the best treatments for Vata Vyadhi. ${ }^{[8]}$ Therefore, Janu Vasti is beneficial for Sandhigatavata. Janu Vasti gives strength to the supporting muscles of the knee joined. Ingredients of Gugguladi Thaila possess Ushna Veerya and it pacifies vitiated Vata Dosha (Table 4). These ingredients have the properties of Katu Rasa, Laghu, Ruksha and Tikshana Guna and Ushnan Veerya. Due to these properties, it pacifies vitiated Kapha Dosha. Hence Gugguladi Thaila is beneficial in treatment of Vata Roga including Sandhigatavata.

\section{Conclusion:}

It is concluded that Ksheera Vaitarana Vasti followed by oral administration of Belimul Thippilimul Ати Inguru Kashaya and Janu Vasti using Gugguladi Thaila is effective in treatment of Sandigatavata (Osteoarthritis).

\section{Limitation of study:}

This is a single case study and this research should be carried out with larger sample which will make results more acceptable.

\section{References:}

1. Murthy KRS. Madhava Nidanam (Roga Vinischaya) 22 /21-2, Chaukhambha Orientalia Varanasi, 1986; p-81

2. Golwalla AF, Golwalla AS. Golwalla Medicine for students, Empress Court, Bombay, 1988; p-1186

3. Murthy KRS. Ashtanga Hrdaya Uttarasthana Vajeekarana Vidhi Adhyaya 40/57. Chaukhambha Sanskrit Series Office Varanasi, 1992; p-420-423

4. Saxena N. Vangasena Samhita or Chikithsa Samgraha of Vangasena Vol.11 Bastikarmadhikara/ 186-190.Chaukhambha Krishnadas Academy Varanasi, 2014; p-1164 -1165

5. Sharma PV. Charaka Samhitha, ChikithsasthanaVatavyadhiChikithsa28/37, Chaukhambha Orientalia, Varanasi, 1986, p$463-464$

6. Kumar P, Clark M. Clinical Medicine, $3^{\text {rd }}$ Edition, London, 1994; p-385-387

7. Anonymous, Gugguladi Thaila, Ayurveda pharmacopeia Vol 1. Part 1, Department of Ayurveda, Colombo, 1969; p-270. 


\section{INTERNATIONAL JOURNAL OF AYUSH CASE REPORTS (IJA-CARE)}

8. Sharma PV. Susruta Samhitha, Chikithsasthana4/8, Chaukhambha Orientalia, Varanasi, 2010; p-304- 305

9. Kotangle AJ, Shrike UJ. The conceptual study of Saindhava Lavana (Rock salt) in Ayurveda and its relevance in modern era A review, Ayush International Interdisciplinary Research Journal, 2020; 7(7):6-10.

10. Resny AR, Indulekha VC, Raj RVB. A critical Ayurvedic Literary review of the plant Amleeka (Tamarindus indica L.), International Ayurvedic Medical Journal, 2018; 1060-1067

11. Sharma PV. Dravyaguna Vijnana, Chaukambha Bharati Academy, Varanasi, 1991; p-35, 55, 60, 121, 277, 333, 456,639

12. Kulkarani S, Itnal SR. Conceptual study on Goksheera as Ajasrika Rasayana, International Ayurvedic Medical Journal, $2019 ; 1124-1127$
13. Anonymous. Ayurveda pharmacopeia Vol 1. Part 3, Department of Ayurveda, Colombo, 1969; p-229.

Conflict of interest: Author declares that there is no conflict of interest.

Guarantor: Corresponding author is guarantor of this article and its contents.

Source of support: None

How to cite this article:

Fernando H.D.R., Ediriweera E.R.H.S.S., Weerasinghe K.D.C.M. Effect of Ksheera Vaitarana Vasti, Janu Vasti along with Adjuvant Ayurveda Drugs in the management of Sandhigatavata (Osteoarthritis in knee joint)- A Case Study. Int. J. AYUSH CaRe. 2021; 5(2):57-63. 